УДК: 618.396-084:618.39-021.3

DOI: 10.24061/2413-4260.VIII.2.28.2018.13

\section{К.В. Дяк}

Вищий державний навчальний заклад України «Буковинський державний медичний університет»,

(м. Чернівці, Україна)

\section{ПРОГНОЗУВАННЯ ПЕРЕДЧАСНИХ ПОЛОГІВ У ВАГІТНИХ ІЗ ЗАГРОЗОЮ ПЕРЕДЧАСНИХ ПОЛОГІВ}

\begin{abstract}
Резюме
Вступ. Проблема передчасних пологів (ПП) є повсякчас актуальною складовою з усіх ускладнень перебігу вагітності. Одним із найбільш перспективних методів прогнозування ПП, наразі, є виявлення фетального фібронектину (ФФ) та визначення вмісту інтерлейкінів, зокрема, має значення інтерлейкін 8 (IЛ-8).

Мета. Визначити ефективність прогнозування передчасних пологів шляхом одночасного визначення ФФ та ІЛ-8 як маркерів вірогідних передчасних пологів.

Матеріал і методи. Проведено клініко-лабораторне обстеження 60 вагітних: 40 - основна група із удаваними перейми до 37 тижнів; 20 - контрольна група, вагітні без даної патології. Визначення ФФ та ІЛ-8 проводили одночасно в сироватці крові та цервікальному слизі з оцінкою результатів на імуноферментному аналізаторі Rider Myltiskan EX за допомогою наборів реактивів і тест-систем.

Результати дослідження. Аналізуючи ефективність діагностики передчасних пологів у вагітних з удаваними переймами до 37 тижнів при використанні трансвагінальної иервікометрії виявлено вкорочення шийки матки в термінах - 22-27 тижнів у 5\% тау 31-33 тижнів у $10 \%$ та зміни з боку показників ФФ в термінах 22-27 тижнів та в 28-33 тижні - де рівень його підвищений, як в сироватці крові, так $і$ в изервікальному

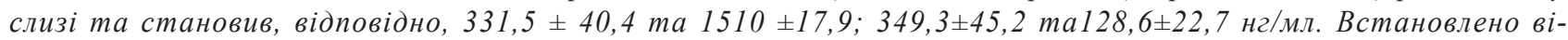
рогідний взаємозв'язок між підвищенням фетального фібронектину та структурними змінами шийки матки (коефіцієнт кореляиії взаємного зв'язку склав $R=0$,50). Враховуючи дані урогенітального мазка та вміст IЛ-8 в иервікальному слизі встановлено, що підвищення кількості лейкоичтів, щзо свідчить про запальний процес, та підвищення ІЛ-8 в 47,8 \% в терміні вагітності 22-27 тижнів+6 днів та у терміні 31-33 тижнів+6 днів у 55,6 \%, де середній показник IЛ-8 становив 132,5 нг/мл та наявність у 33,3\% фонової патологї шийки матки.

Висновки. За наявності хибних перейм і передчасних пологів, не залежно від терміну вагітності, відбувається достовірне підвищення ІЛ-8. Встановлено вірогідний взаємозв'язок між підвищенням фетального фібронектину у сироватиі крові та в иервікальному слизі та структурними змінами шийки матки (коефіцієнт кореляиії взаємного зв'язку склав $R=0,50)$.
\end{abstract}

Ключові слова : передчасні пологи; фетальний фібронектин, інтерлейкін-8, удавані перейми.

\section{Вступ}

Проблема передчасних пологів (ПП) є сталою й повсякчас актуальною складовою наукових досліджень сучасного акушерства. 3 усіх ускладнень перебігу вагітності ПП залишаються найпоширенішим фактором, що значно підвищує рівень перинатальної захворюваності та смертності.

3 огляду на різноманітність етіології ПП і високу частоту ідіопатичного передчасного переривання вагітності, коли його причина залишається нез'ясованою, вчасне прогнозування можливого патологічного перебігу вагітності продовжує викликати значний теоретичний та практичний інтерес науковців і практикуючих лікарів у всьому світі $[3,12]$. Сучасний стан здоров'я жінок репродуктивного віку, акушерські та перинатальні ускладнення протягом гестаційного періоду, у т.ч. загроза ПП, зумовлюють необхідність вирішення питань доцільності госпіталізації, об'єму діагностичних і лікувальних заходів [1]. При цьому слід враховувати той факт, що останніми роками збільшується число жінок, які належать до групи ризику ПП. Тому, сьогодні не припиняється пошук сучасних методів діагностики істинної загрози переривання вагітності. У той же час існують дані, що тільки 20 \% жінок з підозрою на загрозу ПП дійсно народжують передчасно, а у решти
80\% пологи відбуваються після 37 тиж. вагітності.

Таким чином, при визначенні ризику спонтанних ПП ми переважно стикаємось 3 двома групами вагітних - пацієнтками, у яких загрозу ПП підозрюють на основі суб'єктивних скарг, наявності підвищеного тонусу матки за відсутності структурних змін шийки матки, та особами групи ризику з можливим виникненням ПП та переважно ускладненим акушерським анамнезом (невиношування вагітності).

Вивчення біологічних маркерів дозволить краще зрозуміти патологічні механізми, що призводять до спонтанних ПП. Одним із найбільш перспективних методів прогнозування ПП, наразі, є виявлення фетального фібронектину (ФФ) та визначення вмісту інтерлейкінів у крові чи шийкових виділеннях, зокрема, має значення інтерлейкін 8 (ІЛ-8). ФФ є основним глікопротеїном позаклітинного хоріодецидуального матриксу: імуногістохімічними дослідженнями за допомогою моноклональних антитіл встановлено переважну локалізацію ФФ саме на межі хоріонічної (плодової) та децидуальної (материнської) тканин. ІЛ-8 має виражені прозапальні властивості, викликаючи експресію молекул міжклітинної адгезії та посилюючи прилипання нейтрофілів до ендотеліальних клітин і субендотеліальних 
матричних білків, що свідчить про його основну роль в формуванні запальної відповіді.

\section{Мета дослідження}

Визначити ефективність прогнозування передчасних пологів шляхом одночасного визначення ФФ та ІЛ-8 як маркерів вірогідних передчасних пологів.

\section{Матеріал і методи дослідження}

До дослідження включено 40 вагітних із удаваними переймами до 37 тижнів, що перебували на лікуванні у відділенні патології вагітності, екстрагенітальної патології та медицини плода (основна група), та 20 вагітних без удаваних перейм до 37 тижнів (контрольна група). Проведено повне клініко-лабораторне обстеження зі збором анамнезу, акушерським обстеженням, УЗД стану плода та шийки матки, визначенням ФФ та ІЛ-8.

Під час госпіталізації у стаціонар у всіх жінок оцінювали характер скарг (регулярний переймоподібний біль внизу живота), анамнез, об'єктивні дані акушерського обстеження (структурні зміни шийки матки), результати УЗД (розміри шийки матки порівнювали 3 їі показниками під час II скринінгу, характер навколоплідних вод, стан плода та плаценти), визначення ФФ та ІЛ-8 в сироватці крові та цервікальному слизі до вагінального огляду та призначення терапії. Критеріями включення до клінічної групи були відсутність кров'янистих виділень зі статевих шляхів та цілий плідний міхур.

Концентрацію ФФ та ІЛ-8 у сироватці крові та цервікальному слизі визначали на імуноферментному аналізаторі ( IФA) RiderMyltiskan EX за допомогою наборів реактивів і тест-систем для кількісного визначення ФФ (виробник: Cusabio biotech co.,ltd.) та тест-систем для кількісного визначення ІЛ-8 у відповідності до інструкції виробника (Вектор-бест).

Отримані результати наведено у вигляді середніх величин та їхніх стандартних похибок $(\mathrm{M} \pm \mathrm{m})$. Для проведення порівнянь між групами дослідження використано t- критерій Стьюдента. Нульову гіпотезу відкидали при $\mathbf{p}<0,05$. Для аналізу взаємозв'язку двох показників використовували поняття кореляції, де коефіцієнт лінійної кореляції Пірсона (r) вказував, у якій мірі зміна значення одного показника супроводжується зміною іншої ознаки у групі.

\section{Результати дослідження та їх обговорення}

Аналіз анамнестичних даних показав, що середній вік вагітних $(27,7 \pm 3,0)$ років, тобто жінки репродуктивного віку. Середній гестаційний вік на момент проведення аналізу - 26,1 тижнів гестації.

Діагноз удавані перейми виставлявся на підставі скарг, підвищеного тонусу матки та структурних змін шийки матки. У 28 пацієнток діагноз загрози передчасних пологів було встановлено на основі скарг та підвищеного маткового тонусу, в решти 12 жінок, додатково, при цервікометрії, виявлено ознаки загрози переривання вагітності та структурні зміни шийки матки. Ретельний аналіз гінекологічного, акушерського і соматичного анамнезу виявив у всіх вагітних фактори підвищеного ризику передчасних пологів.

Під час госпіталізації у стаціонар вагітні із удаваними переймами скаржилися на переймоподібний біль унизу живота. Особливих причин початку больового синдрому (психоемоційний стрес чи фізичне навантаження) жінки зазначити не могли. Під час огляду відзначено нерегулярний переймоподібний біль внизу живота у вагітних основної групи, матка була у підвищеному тонусі при пальпації відповідно у 4 (10\%) вагітних. Отже, у наше дослідження увійшли пацієнтки 3 переважанням больового синдрому та незначними структурними змінами шийки матки, що можна пояснити раннім зверненням вагітних у стаціонар 3 моменту початку удаваних перейм.

Спектр екстрагенітальної патології вагітних основної групи суттєво не відрізнявся від контрольної та встановлено, що у II триместрі у 18 (45\%) вагітних діагностували анемію, 17 (42,5 \%) - серцево-судинну патологію, включаючи синусову тахікардію та передшлуночкові екстрасистоли, в $2(5 \%)$ - медикаментозну алергію, в 2 (5\%) безсимптомну бактеріурію, у 6 (15\%) - хронічні запальні захворювання в стадії ремісії, такі як хронічний тонзиліт, хронічний цистіт, хронічна герпесна інфекція II типу, піодермія шкіри живота зворотнього розвитку та ін.

У основній групі був вищий відсоток тих, хто повторно народжував - 22 вагітних (55 \%), порівняно 3 пацієнтками, в яких дана вагітність $\epsilon$ першою -18 (45 \%). Серед обстежених пацієнток попередня вагітність завершилась терміновими пологами у 15 (37,5 \%), індукованими пологами шляхом кесарсевого розтину у $3(7,5 \%)$, мимовільним викиднем - у 13 (32,5\%), передчасними пологами - у 3 (7,5 \%), мертвонародженням - у 1 $(2,5 \%)$. Загроза переривання вагітності у першій половині гестації була діагностовано у 13 (32,5\%) пацієнток, у другій половині - у 7 (17,5 \%).

Запальні захворювання піхви діагностували у $20(50 \%)$ вагітних, етіологічний чинник був ідентифікований як Gardnerella vaginalis 3 (7,5\%), Candida albicans - y $11(27,5 \%)$, в решті випадків виявлено змішану бактеріально-грибкову флору. На момент госпіталізації у стаціонар у не виявлено проявів інфекційного захворювання.

Не залежно від стану шийки матки, всім вагітним, після встановлення діагнозу удаваних перейм до 37 тижнів, призначалася терапія, направлена на збереження вагітності: до 25 тижнів - магнію сульфат 20 мл 25\% шляхом внутрішньовенної інфузії з 200 мл ізотонічного розчину натрію хлориду, після 25 тижнів гексопреналіну сульфат 25 мкг (5 мл) у вигляді внутрішньовенних інфузій 3 400 мл ізотонічного розчину натрію хлориду, до 34 тижнів проводилася профілактика синдрому дихальних розладів - внутрішньом'язове введення 24 мг бетаметазону (по 12 мг впродовж двох днів) або 24 мг дексаметазону (по 6 мг кожні 12 год впродовж двох днів ).

Ураховуючи ускладнений акушерський анамнез 3 метою прогнозування передчасних пологів проведено визначення ФФ та ІЛ-8 (табл. 1). 
Таблиця 1

\section{Основні показники ФФ та ІЛ-8}

\begin{tabular}{|c|c|c|c|c|c|c|c|c|}
\hline \multirow[b]{2}{*}{ Показники } & \multicolumn{4}{|c|}{ 5Основна група $\mathrm{n}=40$} & \multicolumn{4}{|c|}{ Контрольна група n=20 } \\
\hline & 22-27+6дн & $28-30+6 д н$ & 31-33+6дн & $\begin{array}{c}34- \\
36+6 д н\end{array}$ & $\begin{array}{c}22- \\
27+6 д \text { дн }\end{array}$ & $\begin{array}{c}28- \\
30+6 д н\end{array}$ & $\begin{array}{c}31- \\
33+6 д н \\
\end{array}$ & $\begin{array}{c}34- \\
36+6 д \mathrm{H} \\
\end{array}$ \\
\hline $\begin{array}{l}\text { Оцінка шийки матки візуально в дзер- } \\
\text { калах \%: } \\
\text { Без структурних змін \% } \\
\text { структурні зміни \% }\end{array}$ & $\begin{array}{l}47,5 \\
12,5 \\
\end{array}$ & $\begin{array}{c}10 \\
5\end{array}$ & $\begin{array}{c}5 \\
15 \\
\end{array}$ & $\begin{array}{l}2,5 \\
2,5 \\
\end{array}$ & $\begin{array}{c}25 \\
- \\
\end{array}$ & $\begin{array}{l}40 \\
- \\
\end{array}$ & $\begin{array}{c}25 \\
- \\
\end{array}$ & $\begin{array}{c}10 \\
- \\
\end{array}$ \\
\hline $\begin{array}{l}\text { Трансвагінальна ехографрія абс. вкоро- } \\
\text { чення шийки матки (<25 мм), \% } \\
\text { відносне вкорочення шийки } \\
\text { матки (> } 25 \text { мм), \% } \\
\end{array}$ & $\begin{array}{r}5 \\
12,5 \\
\end{array}$ & $\begin{array}{l}- \\
10 \\
\end{array}$ & $\begin{array}{r}10 \\
7,5 \\
\end{array}$ & $\begin{array}{l}2,5 \\
- \\
\end{array}$ & - & - & - & - \\
\hline $\begin{array}{l}\text { Тест на фетальний фібронектин,М士m } \\
\text { Сироватка крові нг/мл } \\
\text { Цервікальний слиз нг/мл }\end{array}$ & $\begin{array}{c}331,5 \pm 40,4 \\
1510 \pm 17,9^{*} \\
\end{array}$ & $\begin{array}{c}288 \pm 75,5^{*} \\
3553,5 \\
\end{array}$ & $\begin{array}{l}390 \pm 46,5 \\
54513,1 \\
\end{array}$ & $\begin{array}{c}225 \pm 75,4 \\
-\end{array}$ & $\begin{array}{l}296 \pm 35,6 \\
450 \pm 8,3^{*} \\
\end{array}$ & $\begin{array}{l}148, \pm 6,2^{*} \\
415 \pm 16,7 \\
\end{array}$ & $\begin{array}{c}320 \pm 69 \\
425 \pm 25,6 \\
\end{array}$ & $\begin{array}{c}400 \pm 0 \\
- \\
\end{array}$ \\
\hline & \multicolumn{4}{|c|}{ Основна група $n=40$} & \multicolumn{4}{|c|}{ Контрольна група n=20 } \\
\hline Показники & 22-27+6дн & 28-30+6дн & 31-33+6дн & $\begin{array}{c}34- \\
36+6 д н\end{array}$ & $\begin{array}{c}22- \\
27+6 д н\end{array}$ & $\begin{array}{c}28- \\
30+6 д н\end{array}$ & $\begin{array}{c}31- \\
33+6 д н\end{array}$ & $\begin{array}{c}34- \\
36+6 д н\end{array}$ \\
\hline 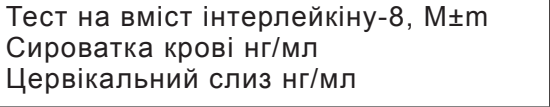 & $\begin{array}{l}31,6 \pm 4,5^{*} \\
19,6 \pm 2,7\end{array}$ & $\begin{array}{c}19,2 \pm 2,5^{*} \\
20 \pm 7,4\end{array}$ & $\begin{array}{c}30,6 \pm 6,9^{*} \\
26,5 \pm 3,5\end{array}$ & \begin{tabular}{|l}
$95 \pm 23,7^{*}$ \\
$32,5 \pm 2,5$
\end{tabular} & $\begin{array}{c}6 \pm 0,8 \\
86,3 \pm 1,9\end{array}$ & $\begin{array}{c}6,3 \pm 0,3 \\
60 \pm 7.4\end{array}$ & $\begin{array}{c}6,5 \pm 0,5 \\
65 \pm 4,8\end{array}$ & $\begin{array}{c}3,5 \pm 0,2 \\
-\end{array}$ \\
\hline $\begin{array}{l}\text { Урогенітальний мазок \% } \\
\text { Норма \% } \\
\text { Патологічний \% }\end{array}$ & $\begin{array}{c}10 \\
47,5^{*}\end{array}$ & $\begin{array}{c}10 \\
5\end{array}$ & $\begin{array}{c}10 \\
12,5 \text { * }\end{array}$ & $\begin{array}{l}2,5 \\
2,5\end{array}$ & $\begin{array}{l}10 \\
20\end{array}$ & $\begin{array}{c}20 \\
-\end{array}$ & $\begin{array}{c}10 \\
5\end{array}$ & $\overline{5}$ \\
\hline
\end{tabular}

\section{* достовірний показник $p<0,05$}

Оцінюючи дані об'єктивного дослідження шийки матки в дзеркалах, виявлено структурні зміни шийки матки в залежності від терміну гестації у 22-27 тижнів + 6 днів та 31-33 тижні+6 днів, відповідно, 12,5 \% та $15 \%$ на відміну від групи контролю (табл.1).

Аналізуючи ефективність діагностики передчасних пологів у вагітних з удаваними переймами до 37 тижнів при використанні трансвагінальної цервікометрії виявлено вкорочення шийки матки (менше 25 мм), відповідно, до структури передчасних пологів: в термінах - 22-27 тижнів, 31-33 тижні та 34-36 тижнів, відповідно, 5 \%, $10 \%$ та 2,5 $\%$, а показники відносного вкорочення шийки матки були у підгрупах в термінах з 22 до 34 тижнів $-12,5 \%, 10 \%$ та $7,5 \%$ (табл. 1$)$.
У відповідності до об'єктивних змін з боку шийки матки та трансвагінальної цервікометрії, паралельно, є зміни з боку показників ФФ, відповідно, в терміні 22-27 тижнів та в терміні 28-33 тижні - рівень його підвищений, як в сироватці крові, так і в цервікальному слизі та становить, відповідно, $331,5 \pm 40,4$ та $1510 \pm 17,9 ; 349,3 \pm 45,2$ та128,6 $\pm 22,7($ табл.1). Однак, ефективність його діагностики 3 метою прогнозування передчасних пологів не обгрунтоване після 34 тижнів.

Для підтвердження ролі ФФ в генезі передчасної пологової діяльності на основі дослідження довжини шийки матки, ми вдалися до застосування кореляційного аналізу, який показав ступінь взаємного зв'язку між явищами - рівнем ФФ у цервікальному слизі та довжиною шийки матки за даними цервікометрії (Рис.1).

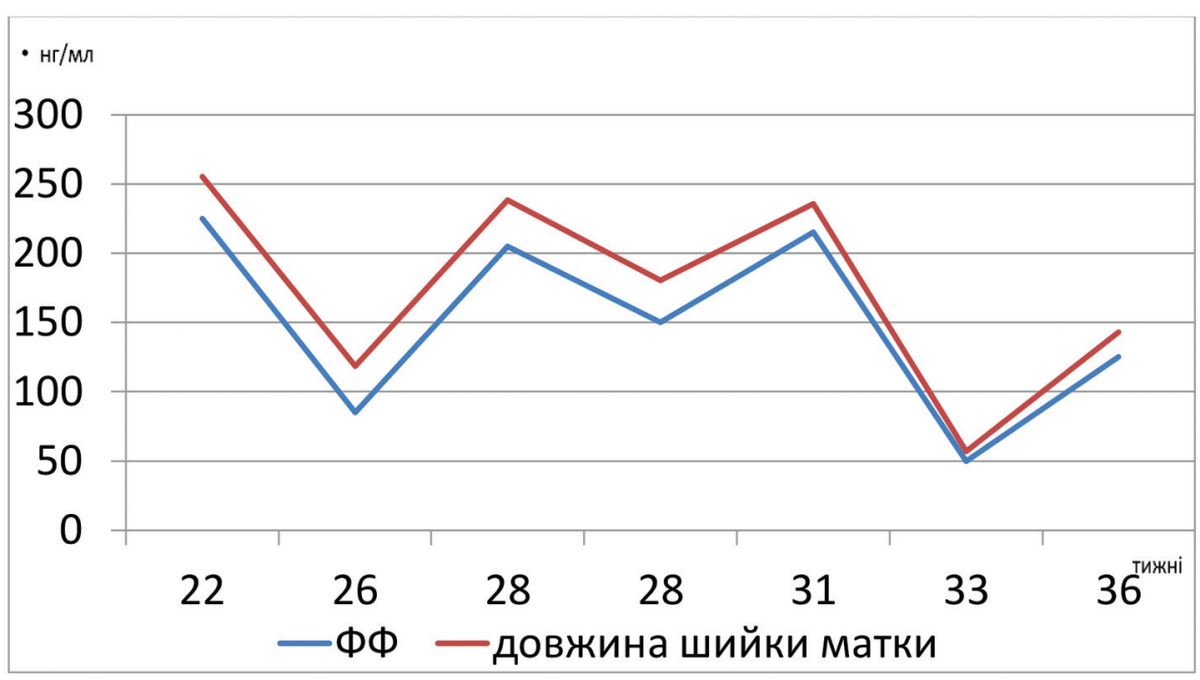

Коефріцієнт кореляції взаємного зв'язку склав $R=0,50$ 
Обидва показники є свідченням достатнього зв'язку між явищами та, з огляду на складність процесу ініціації пологової діяльності, множинного впливу на нього інших чинників, цей результат є достатньо вірогідним.

Визначивши кількісний вміст ІЛ-8 у вагітних основної групи, встановлено, що у всіх підгрупах спостерігається достовірне підвищення у сироватці крові та, паралельно, незначне підвищення у цервікальному слизі, не залежно від терміну вагітності, тобто у всіх випадках підвищеного тонусу матки, відповідних скарг і структурних змін шийки матки.

Враховуючи, що ІЛ-8 є прозапальним цитокіном, визначили наявність місцевого запального процесу проведенням бактеріоскопічного досліджень виділень із піхви та наявністю фонової патології шийки матки. При цьому, встановлено, що підвищення кількості лейкоцитів, що свідчить про запальний процес, та підвищення IЛ-8 в 47,8 $\%$ в терміні вагітності 22-27 тижнів+6 днів за наявності фонової патології шийки матки.

У терміні 28-30 тижнів+6 днів встановлено патологічне підвищення кількості лейкоцитів у піхвовому вмісті тільки в 16,7 \% випадків, де середній показник ІЛ-8 становив 40,0 нг/мл, який втричі менший ніж в основній групі та відсутня фонова патологія шийки матки.

У терміні 31-33 тижнів+6 днів встановлено наявність інфекційного процесу в піхві у 55,6 \%, де середній показник ІЛ-8 становив 132,5 нг/мл та наявність у 33,3 \% фонової патології шийки матки.

Після 34 тижнів вагітності спостерігалися аналогічні зміни - достовірне підвищення ІЛ-8 у цервікальному слизі з середнім показником 65,0 нг/ мл за наявності запальних змін в піхві та фонової патології шийки матки.Тобто ІЛ-8 підвищується як за наявності ознак хибних перейм, так і у випадку передчасних пологів, при наявності чи відсутності запальних змін в піхві.

Враховуючи дані урогенітального мазка та особливості вмісту ІЛ-8 в цервікальному слизі у жінок основної та контрольної груп для аналізу взаємозв'язку між цими показників використали кореляційний аналіз (Рис.2).

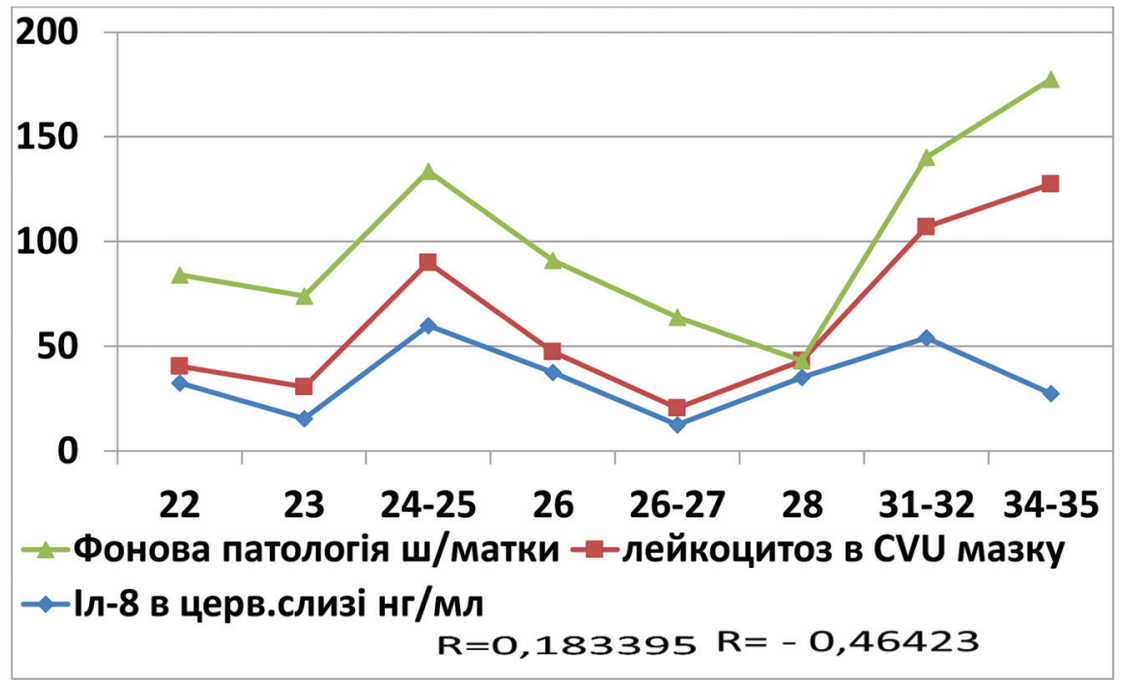

Проведений кореляційний аналіз між кількістю лейкоцитів в урогенітальному мазку та вмістом прозапального цитокіну ІЛ-8, коефіцієнт кореляції склав $\mathrm{R}=0,18$ (помірний зв'язок), тобто незначну пряму залежність.

Таким чином, обстеження вагітних із загрозою передчасної пологової діяльності в різні гестаційні терміни встановило неоднорідність груп за наявністю лейкоцитозу в урогенітальному мазку, як можливого етіологічного чинника ПП, виявлено лише в першій та третій підгрупі обстежених.

Проте, для визначення ролі ІЛ-8 в генезі передчасної пологової діяльності на основі фонової патології шийки матки, кореляційний аналіз показав $\mathrm{R}=-0,46423$, пряму обернену залежність від даної нозології.

\section{Висновки}

1. Встановлено достовірне підвищення ІЛ-8 за наявності хибних перейм і передчасних пологів не залежно від терміну вагітності, тобто у всіх випадках підвищеного тонусу матки, відповідних скарг і структурних змін шийки матки.

2. Визначення фетального фібронектину є маркером передчасних пологів у терміні 22-27 тижнів та в терміні 28-30 тижні+6 днів вагітності у відповідності до об'єктивних змін з боку шийки матки та трансвагінальної цервікометрії, оскільки рівень його достовірний в сироватці крові та в цервікальному слизі, становить, відповідно, $1510 \pm 17,9 ; 288 \pm 75,5$.

3. Встановлено вірогідний взаємозв'язок між підвищенням фетального фібронектину у сироватці крові та в цервікальному слизі та структурними змінами шийки матки (коефіцієнт кореляції взаємного зв'язку склав $\mathrm{R}=0,50)$.

4. Підвищення IЛ-8 у цервікальному слизі до 33,92 нг/мл за наявності болючих скорочень матки у терміні вагітності 22-30,6 тижнів передує появі структурних змін шийки матки, залежить від наявності запального процесу в піхві (коефіцієнт кореляції $\mathrm{R}=0,18$ ) та фонової патології шийки матки, $(\mathrm{R}=-0,46423)$.

\section{Перспективи подальших досліджень}

Розробити чіткі критерії для визначення фетального фібронектину та інтерлейкіну-8 залежно від скарг, мікроцинозу піхви та стану шийки матки з метою формування групи ризику по передчасних пологах і своєчасної діагностики ускладнень у вагітних групи ризику.

Конфлікт інтересів: Автори не заявляли будь-якого конфлікту інтересів. 


\section{Література}

1. Dodd JM, Jones L, Flenady V, Cincotta R, Crowther CA. Prenatal administration of progesterone for preventing preterm birth in women considered to be at risk of preterm birth [Internet]. Cochrane Database Syst Rev. 2013 [cited 2018 Feb 8];7:CD004947. Available from: http:// cochranelibrary-wiley.com/doi/10.1002/14651858.CD004947.pub3/ abstract;jsessionid=DE34C5DDEA5DE511861FD019543FCD2D f02t01 doi: 10.1002/14651858.CD004947.pub3

2. Singh S, Singh S, Chandra M, Rani R, Verma S. A Study to Evaluate the Efficacy of Actim Partus (A Rapid Bedside Test) in the Prediction of Preterm Labor. Obstetrics and Gynecology. Indian Journal of clinical Practice. 2013;24(3):260-3

3. Goganau AM, Patrascu A, Novac L. Evaluation of pregnant women at risk of preterm delivery by correlating ultrasound markers with Insulin-like growth factor binding protein-1. Gineco.eu. 2014;10(36):62-5.

4. Novac L. The cost assessment of fetal fibronectin testing in suspected premature Final protocol. Klejen Systematic rewiew Ltd. Assessment group, HTA, 2011.

5. Ruma MS, Bittner KC, Soh CB. Current Perspectives on the Use of Fetal Fibronectin Testing in Preterm Labor Diagnosis and Management [Internet]. Am J Manag Care. 2017[cited 2018 Feb 19];23(19):S356-62. Available from: http://www.ajmc.com/journals/ supplement/2017/management-of-preterm-birth-current-practiceschallenges-and-opportunities/current-perspectives-on-the-use-offetal-fibronectin-testing

6. Пирогова ВI, Шурпяк СО, Ошуркевич ОЕ. Шляхи оптимізації діагностики загрози передчасних пологів. Медицинские аспекты здоровья женщины. 2011;7:18-24.

7. Жук CI, Таран OA, Кошмеринська АМ. Перспективи застосування тест-системи «Фемофлор 16» при дисбіозі піхви. Здоровье женщины. 2013;1:159-61.

8. Рибони Ф, Витуло А, Дель'аванцо М, Плебани М, Баттаджлиарин Дж, Патерностер Д. Биохимические маркеры при прогнозировании преждевременных родов: фосфорилированный протеин-1, связывающий инсулиноподобный фактор роста и фетальный фибронектин. Репродуктивное здоровье Восточная Европа. 2013;5(29):30-7.

9. Jung EY, Park JW, Ryu A, Lee SY, Cho SH, Park KH. Prediction of impending preterm delivery based on sonographic cervical length and different cytokine levels in cervicovaginal fluid in preterm labor. $J$ ObstetGynaecol Res. 2016;42(2):158-65. doi: 10.1111/jog.12882.

\section{ПРОГНОЗИРОВАНИЕ ПРЕЖДЕВРЕМЕННЫХ РОДОВ У БЕРЕМЕННЫХ С УГРОЗОЙ ПРЕЖДЕВРЕМЕННЫХ РОДОВ}

\author{
К.В. Дяк \\ Высшее государственное учебное \\ заведение Украины \\ «Буковинский государственный \\ медицинский университет» \\ (Украина, г. Черновцы)
}

\section{Резюме}

Введение. Проблема преждевременных родов (ПП) является постоянно актуальной составляющей из всех осложнений течения беременности. Одним из наиболее перспективных методов прогнозирования ПР является выявление фетального фибронектина (ФФ) и определение содержания интерлейкинов в крови или шеечных выделениях, в частности, имеет значение интерлейкин 8 (ИЛ-8).

Цель. Определить эффективность прогнозирования преждевременных родов путем одновременного определения ФФ и ИЛ-8 в качестве маркеров возможных преждевременных родов.

Материалы и методы. Проведено клиниколабораторное обследование 60 беременных : 40 основная группас ложными схватки до 37 недель; 20 - контрольная группа, беременные без данной патологии. Определение ФФ и ИЛ-8 проводили одно-

\section{References}

1. Dodd JM, Jones L, Flenady V, Cincotta R, Crowther CA. Prenatal administration of progesterone for preventing preterm birth in women considered to be at risk of preterm birth [Internet]. Cochrane Database Syst Rev. 2013 [cited 2018 Feb 8];7:CD004947. Available from: http://cochranelibrary-wiley. com/doi/10.1002/14651858.CD004947.pub3/ abstract;jsessio nid=DE34C5DDEA5DE511861FD019543FCD2D.f02t01 doi: 10.1002/14651858.CD004947.pub3

2. Singh S, Singh S, Chandra M, Rani R, Verma S. A Study to Evaluate the Efficacy of Actim Partus (A Rapid Bedside Test) in the Prediction of Preterm Labor. Obstetrics and Gynecology. Indian Journal of clinical Practice. 2013;24(3):260-3.

3. Goganau AM, Patrascu A, Novac L. Evaluation of pregnant women at risk of preterm delivery by correlating ultrasound markers with Insulinlike growth factor binding protein-1. Gineco.eu. 2014;10(36):62-5.

4. Novac L. The cost assessment of fetal fibronectin testing in suspected premature Final protocol. Klejen Systematic rewiew Ltd. Assessment group, HTA, 2011.

5. Ruma MS, Bittner KC, Soh CB. Current Perspectives on the Use of Fetal Fibronectin Testing in Preterm Labor Diagnosis and Management [Internet]. Am J Manag Care. 2017[cited 2018 Feb 19];23(19):S356-62. Available from: http://www.ajmc.com/ journals/supplement $/ 2017 /$ management-of-preterm-birth-currentpractices-challenges-and-opportunities/current-perspectives-onthe-use-of-fetal-fibronectin-testing

6. Pyrohova VI, Shurpiak SO, Oshurkevych OE. Shliakhy optymizatsii diahnostyky zahrozy peredchasnykh polohiv [Ways of optimizing the diagnosis of the threat of preterm delivery]. Medytsynskye aspektы zdorovia zhenshchynы. 2011;7:18-24. (in Ukrainian).

7. Zhuk SI, Taran OA, Koshmerins'ka AM. Perspektivi zastosuvannya test-sistemi «Femoflor 16» pri disbiozi pikhvi [The prospects of a test system «Femoflor 16» with vaginal dysbiosis]. Zdorov'e zhenshchiny. 2013;1:159-61 (in Ukrainian).

8. Riboni F, Vitulo A, Del"avantso M, Plebani M, Battadzhliarin Dzh, Paternoster D. Biokhimicheskie markery pri prognozirovanii prezhdevremennykh rodov: fosforilirovannyy protein-1, svyazyvayushchiy insulinopodobnyy faktor rosta $i$ fetal'nyy fibronektin [Biochemical markers in predicting preterm birth: phosphorylated protein-1, binding insulin-like growth factor and fetal fibronectin]. Reproduktivnoe zdorov'e Vostochnaya Evropa. 2013;5(29):30-7 (in Russian).

9. Jung EY, Park JW, Ryu A, Lee SY, Cho SH, Park KH. Prediction of impending preterm delivery based on sonographic cervical length and different cytokine levels in cervicovaginal fluid in preterm labor. J ObstetGynaecol Res. 2016;42(2):158-65. doi: 10.1111/jog.12882.

\section{PREVENTION OF PREMATURE LABOR IN PREGNANT WOMEN WITH PREVIOUS PREVENTION}

\section{K. V. Dyak}

\author{
Higher State Educational \\ Establishment \\ of Ukraine «Bukovinian \\ State Medical University»" \\ (Chernivtsi, Ukraine).
}

\section{Summary}

Introduction. The problem of preterm labor is always relevant component of all complications of pregnancy. One of the most promising methods for predicting preterm labor is, at present, the detection of fetal fibronectin (fFN) and the determination of the content of interleukins in the blood or cervical secretions, in particular, the importance of interleukin 8 (IL-8).

Aim. Determine the efficiency of prediction of preterm labor by simultaneously identifying fFN and IL-8 as markers of probable preterm labor.

Materials and methods. Clinical and laboratory examination of 60 pregnant women was carried out: 40 - the main group with false contractions up to 37 weeks; 20 - control group, pregnant without this pathology. Definition of fFN andIL- 8 was performed simultaneously in blood serum and cervical mucus 
временно в сыворотке крови и цервикальной слизи с оценкой результатов на иммуноферментном анализаторе Rider Myltiskan EX с помощью наборов реактивов и тест-систем.

Результаты исследования. Анализируя эффективность диагностики преждевременных родов у беременных с ложными схватками до 37 недель при использовании трансвагинальной цервикометрии выявлено укорочение шейки матки в сроках - 22-27 недель в 5\% и в $31-33$ недель у $10 \%$ и изменения со стороны показателей ФФ в терминах 22- 27 недель и в 28-33 недели - где уровень его повышен, как в сыворотке крови, так и в цервикальной слизи и составил, соответственно, $331,5 \pm 40,4$ и $1510 \pm 17,9$; $349,3 \pm 45,2$ и $128,6 \pm 22,7$ нг / мл. Установлено достоверная взаимосвязь между повышением фетального фибронектина и структурными изменениями шейки матки (коэффициент корреляции взаимной связи составил $\mathrm{R}=0,50)$. Учитывая данные урогенитального мазка и содержание ИЛ-8 в цервикальной слизи установлено, что повышение количества лейкоцитов, что свидетельствует о воспалительном процессе, и повышение ИЛ-8 в 47,8\% в сроке беременности 22-27 недель +6 дней и в сроке 31 - 33 недель +6 дней в 55,6\%, где средний показатель ИЛ-8 составлял 132,5 нг / мл и наличие у $33,3 \%$ фоновой патологии шейки матки.

Выводы. При наличии ложных схваток и преждевременных родов, независимо от срока беременности, происходит достоверное повышение ИЛ-8. Установлено достоверная взаимосвязь между повышением фетального фибронектина в сыворотке крови и в цервикальной слизи и структурными изменениями шейки матки (коэффициент корреляции взаимной связи составил $\mathrm{R}=0,50)$.

Ключевые слова: преждевременные роды; фетальный фибронектин, интерлейкин-8, ложные схватки.

\section{Контактна інформація:}

Дяк Крістіна Вікторівна - аспірант кафедри акушерства та гінекології та викладач коледжу Вищого державного навчального закладу України «Буковинський державний медичний університет» (м. Чернівці, Україна)

Контактна адреса: площа Театральна, 2 м.Чернівці, 58002, Україна.

Контактний телефон: +38 (093) 2550348.

() К.В.Дяк, 2018 with the evaluation of the results on the Rider Myltiskan EX immuno-enzyme analyzer using a set of reagents and test systems.

Research results. An analysis of the effectiveness of diagnosis of preterm labor in pregnant women with false contractions up to 37 weeks using transvaginal cervicomercia revealed a shortening of the cervix in terms of 22-27 weeks in 5\% and in 31-33 weeks in $10 \%$ and changes from the FF values in terms of 22- 27 weeks and 28-33 weeks - where its level was elevated both in serum and in cervical mucus and was $331.5 \pm 40.4$ and $1510 \pm 17.9$ respectively; $349.3 \pm 45.2$ and $128.6 \pm 22.7 \mathrm{ng} / \mathrm{ml}$. The probable correlation between increased fetal fibronectin and structural changes in the cervix was established (the correlation coefficient of the reciprocal connection was $\mathrm{R}=0.50)$. Taking into account the data of urogenital stroke and the content of IL- 8 in cervical mucus, it was found that an increase in the number of leukocytes, indicating inflammation, and an increase in IL-8 in $47.8 \%$ during the period of pregnancy 22 27 weeks +6 days and in the $31-33$ weeks +6 days in $55.6 \%$, where the mean IL-8 was $132.5 \mathrm{ng} / \mathrm{ml}$ and $33.3 \%$ of the background cervical cancer.

Conclusions. In the presence of false breaks and premature births, regardless of the period of pregnancy, there is a significant increase in IL-8. The probable correlation between increased fetal fibronectin in blood serum and in cervical mucus and structural changes in the cervix (correlation coefficient of mutual communication was $\mathrm{R}=0.50$ ) was established.

Key words: Preterm Labor; Fetal Fibronectin, Interleukin-8, False Contractions.
Контактная информация:

Дяк Кристина Викторовна - аспирант кафредры акушерства и гинекологии и преподаватель колледжа Высшего государственного учебного заведения Украины «Буковинский государственный медицинский университет» (г..Черновцы, Украина) Контактный адрес: площадь Театральная, 2, Черновцы, 58002, Украина. Контактный телефон: +38 (093) 2550348

\section{Contact Information:}

Kristina Dyak - a post-graduate student of the Department of Obstetrics and Gynecology and a lecturer at the College of the Higher State Educational Establishment of Ukraine «Bukovinian State Medical University» (Chernivtsi, Ukraine).

Contact address: 2 Teatralna Square, Chemivtsi, 58002, Ukraine.

Contact phone: +38 (093) 2550348. 